\title{
GENDER ANALYSIS OF SEXUAL MISCONDUCT IN UN PEACEKEEPING OPERATIONS
}

\author{
Rikianarsyi Arrassyidinta Naramanik Wirantoputri \\ School of Advanced International Studies; Johns Hopkins University; United States of America: \\ rnarama1@jh.edu
}

\begin{abstract}
Abstrak
Penelitian ini bertujuan untuk mengeksplorasi faktor penyebab tetap terjadinya eksploitasi dan pelecehan seksual yang dilakukan oleh pasukan perdamaian Perserikatan Bangsa-bangsa (PBB) terhadap perempuan lokal di negara konflik. Penelitian ini menggunakan analisis gender, pendekatan kualitatif dan studi literatur. Hal yang dikaji dalam penelitian ini yakni kebijakan PBB mengenai pelarangan beragam jenis relasi seksual pasukan perdamaian PBB dan perempuan lokal, data laporan tuduhan eksploitasi dan pelecehan seksual yang disampaikan penduduk, dan Indeks Perempuan, Perdamaian, dan Keamanan (WPS Index) dari negara pengirim dan penerima pasukan perdamaian PBB. Penelitian ini berargumen bahwa dalam penugasan misi perdamaian, terdapat aspek gender yang diabaikan oleh PBB, yakni budaya patriarki di kedua kelompok negara, pandangan/ gagasan hipermaskulin dari pasukan militer, dan tujuan berdimensi gender dari negara pengirim yang ingin membentuk dan mempertontonkan identitas mereka sebagai pelindung. Penelitian ini menyarankan kepada PBB agar mengkaji WPS Index negara pengirim sebelum menerima pasukan perdamainnya.
\end{abstract}

Kata Kunci: Analisis Gender, Eksploitasi dan Pelecehan Seksual, Pasukan Perdamaaian PBB, WPS Index

\begin{abstract}
This study aims to explore the factors that lead to the persistence of sexual exploitation and abuse against local women by UN peacekeeping personnel. The study applies gender analysis and employs a qualitative approach and literature review. This study contrasts the United Nations (UN) policies to prohibit sexual relations in peacekeeping missions and the statistics of sexual misconduct allegations, then examines the Women, Peace, and Security (WPS) Index of both contributing and host countries. The paper argues that in deploying the missions the UN overlooks the gender aspects, such as the patriarchal cultures in the host and contributing countries, the hyper-masculine ideas of the military troops, and the gendered intention of the contributing countries to form and perform their identity as the protector. This study suggests the UN assessing the WPS Index of the Member States before welcoming their peace forces.
\end{abstract}

Keywords: Gender Analysis, Sexual Exploitation, and Abuse, UN Peacekeeping Missions, WPS Index 


\section{Introduction}

Peacekeeping operations is one of the gendered topics in International Relations and has a strong private, sexual implication to local communities, especially women, living in areas where the operations are deployed. However, the attention to the topic has been neutrally masked and focused on how the international operations support internal ceasefire agreements, rebuild local societies, re-elect a legitimate regime, and other works in creating a peaceful and stable condition inside a chaotic country. News broke in 2002 when a report by the UNHCR and Save the Children revealed sexual exploitation committed by peacekeeping members to girls sheltered in the UNHCR camps. Started in 2003, the UN has started a series of steps to address sexual misconduct cases in all peacekeeping operations. Among the measures were launching the Zero Tolerance Policy to prohibit sexual relations between peacekeeping members and local civilians and producing annual reports regarding sexual exploitation and abuse. The UN also established the new post of the Special Representative of the Secretary-General on Sexual Violence in Conflict to acknowledge the adverse impact of sexual violence in conflict to communities. For the victims, the UN has developed a reporting mechanism to file sexual misconduct committed by peacekeepers and created a trust fund to support the victims. To the contributing countries which forces committed sexual exploitation and abuse, the UN has built a communication mechanism to monitor the progress of national prosecution against the perpetrators. Regardless of these robust UN efforts, the reports of alleged sexual misconduct by peacekeeping personnel have never stopped.

This paper argues that the underlying factor which makes sexual misconduct by peacekeepers has not ceased is the unequal gender relations attached under the framework of patriarchal societies. These cultures have been cultivated not only in countries hosting the peacekeeping operations but also in the peacekeeping contributing countries. Meanwhile, the UN initiatives in addressing sexual misconduct are too broad and general, correcting the past mistakes, patching the rising holes, and relying on national governments' responsibility. Having been aware that the number of sexual misconduct allegations often rises from the previous year, the UN still deploys peacekeeping missions from the same contributing countries that have a record of committing sexual exploitation and abuse to local women. 
It is intriguing to note that after the mission in Bosnia and Herzegovina ended at the end of the 20th century, developing countries that have a history of internal conflict or economically poor have dominated the list of top contributing countries to peacekeeping missions. Meanwhile, in 1948 when the UN launched its first peacekeeping operation to the end of the 1990s, the top contributor countries were Developed European countries. Both groups' discrepancy is not limited to the defensive capability and military logistical supplies, but also to the level of patriarchal cultures with the elements of misogynistic views, gender inequality, and a tendency to subordinate women.

The Women, Peace, and Security (WPS) Index reveals the gender discrepancy of both groups of countries. The WPS Index of developed European countries is high, which signifies the better performance of gender equality and the low level of violence against women. Meanwhile, the developing African countries are placed at the bottom of the Index, showing that in these countries women are placed lesser than men and violence against women is common. With this discrepancy in WPS scores and the fact the UN still deploys missions from the bottom WPS Index countries to protect civilians in the same low WPS Index countries, there is a possibility that the UN overlooks the gender risks attached to the operations. It is surely impossible to halt all UN peacekeeping personnel deployments as these missions are critical to maintaining international security and peace. To minimize the risk of sexual misconduct by the personnel, therefore, the UN should integrate gender perspectives in the peace operations assessment and deployment.

This study will explore the gender aspects that lead to the persistence of sexual exploitation and abuse in UN peacekeeping missions. Analyzing the gender aspect is fundamental. This analysis reveals the root of the problem that the UN overlooked when it focused on prohibition, investigation, national prosecution, and retribution policies.

\section{Patriarchy}

\section{Patriarchy and Conflict}

In analyzing sexual violence against women in a conflict situation, focusing on the patriarchal cultures is essential. First, within the patriarchal cultures, there is a sense of misogyny, unequal gender relations as well as women subordination. Women are seen as 
an object who are weak, vulnerable, helpless and play a role as the support providers for men. This subordination is not only cultivated inside women's houses, but it is extended to public spheres and grown through economic, legal, social, and cultural institutions (Ticker, 1992). Barter for this subordination is protection by men, which as a consequence, women are placed lesser than men (DeLargy, 2013).

During a peaceful situation, the patriarchal structures may not be seen. Women can participate in public spheres, such as education, political activism, governmental seats, economic markets, social and cultural activities, etc., but this permit will be taken away when the situation is reversed to conflict. In a conflict or war situation, the patriarchal cultures become more intense and the division of gender is exacerbated, with men having a more legitimate role as the protector, while women are forced to be the protected and the supporter for men (Kapur \& Rees, 2019). In this situation, women are withdrawn from public life and manipulated to hand over their freedoms to men until peace is achieved. However, while waiting for the peace, women become poorer and are more prone to violence. They lack of income and have limited access to the property, education, employment, and other public participation. The more women are deprived of this access, the deeper subordination they experience. Heidi Hudson calls this chain as the "link of gender inequality and violence" (Hudson, 2010).

The patriarchal cultures appear more intense in a military environment. Before being enlisted, male soldiers were civilians who socialized with each other through peaceful relations. However, when they joined the military, they face a combat situation, where pacific values held by civilians are no longer relevant (DeLargy, 2013). Here the process of resocialization begins. To survive, the combatants are then trained to cultivate new "hyper-masculine" attributes, such as "aggressiveness, competitiveness, misogyny, violence and dominance" (DeLargy, 2013). They grow a strong sense of fraternity and obedience to the unit they belong and experience the peer pressures to replicate and protect one another (DeLargy, 2013).

Combining these hyper-masculine characteristics in the military and the deeper subordination of women in the civilian societies during the conflict, the relations between male troops and female civilians turn to be more misogynist, dominant and violent. In numerous conflicts and wars, Cynthia Enloe observes these relations are manifested in 
"militarized rape and militarized prostitution" (Enloe, 2000). Women then are vulnerable to sexual abuse and exploitation tied to the personnel who live in the military stations.

UN peacekeeping mission falls within the discourse of the patriarchal cultures and military operations. Although the missions are constituted by military, police, and civilian experts, and they are external entities sent to monitor the on-going conflict and peace process, instead of being the combatants, they are predominantly consisted of male military troops and deployed in war areas. These shared characteristics are the foundation of Enloe's argument that nothing in the peacekeeping operations' structures exempts the soldiers to act less sexist to the communities they are deployed to (Enloe, 2000).

\section{Patriarchy and State Formation}

The gendered process attached in the patriarchal cultures is also exercised and experienced by states in their interaction at the international system (Wadley, 2010). There are two elements in this argument. First, a state's identity is not a given or complete product, instead it is an on-going process. This view is derived from Jackson and Nexon's theory of "state project" on how the states are forming and changing. In the state project, states are formed through two stages, namely "state formation" and "yoking" (Jackson \& Nexon, 1999). During the first stage of the state project, states socially interact with each other and develop a system of ties that constructs and reconstructs state borders and establishes sovereignty (Jackson \& Nexon, 1999). This process is essential but has yet substantiated the state as the capable one. For a state to be seen as a distinct, unitary, capable entities, it must enter the second stage, which is "yoking", or connecting "two or more proto-boundaries or site of difference, such that one side of each becomes defined as 'inside' the same entity" (Jackson \& Nexon, 1999). In other words, in the yoking stage, a state repeatedly performs actions that previously are alien, but these acts are accepted by the external audience as activities that states with a particular identity usually and normally do.

Second, Wadley combines Jackson and Nexon's state project with Judith Butler's theory of performativity. There are similarities between state-formation and individual's performativity because both states and individuals produce meaningful intersubjective 
relations (Wadley, 2010). They substantiate their existence by replicating and repeating the norms of being socially comprehensible. Hence, building upon Butler's performativity theory that points out the existence of "gender" as one of the recipes in individuals' social relations, gendered process is also attached in state-formation. As states want to substantiate their existence by being powerful, states tend to perform activities that are classified by the patriarchal cultures as masculine. Possessing and carrying out the capability to protect is one of the masculine activities to preserve states' existence (Wadley, 2010).

Moreover, Wadley elaborates the effects of this performativity on the protected, which is female citizens. First, the relations between the protector and the protected become "gendered and unequal" and second, they do not receive protection as much as they are promised (Wadley, 2010). This is natural because states only intend to gain the masculine reputation, instead of sincerely protecting. The result at the individual level is alarming: within societies that the women are already suffered from the gendered relations in their households, protection performativity by states exacerbates their subservience.

\section{Methods of Study}

This research employs the qualitative method, with literature review as the main tool to analyze the phenomena. The data relating to the UN peacekeeping missions and victims of sexual exploitation are public data extracted from the UN websites. Meanwhile, to measure the inequal gender relations that subordinate women inside a country, this study cites the result of the Women, Peace, and Security (WPS) Index 2019/2020 that assess women's security, prosperity and inclusion worldwide. The Index is calculated by merging three fundamental elements of women's prosperity, namely "1) inclusion (education, financial inclusion, employment, cellphone use, parliamentary representation), 2) justice (formal laws and informal discrimination) and 3) security (intimate partner violence, community safety, organized violence)" (Georgetown University's Institute for WPS, 2019).

Through its aforementioned elements, the WPS Index signifies, among others, the links between domestic violence and women's security, the condition of conflict-related sexual violence, the degree of masculinity and gender inequality, the health condition of 
women, and the possibility of war. From the result of the WPS Index, it can be seen that the majority of peacekeeping contributing countries, especially those from developing, Africa, and South Asia region are among the worst performer countries. Their ranks are even similar to the host countries where their peace forces are stationed.

\section{Sexual Exploitation and Abuse in UN Peacekeeping Missions}

UN peacekeeping missions are UN-mandated peace operations deployed to post-conflict areas following peace or ceasefire agreements between disputing parties. The deployment of the missions is one of the UN efforts to implement its purpose in Article 1 of the UN Charter to maintain international peace and security. It is also part of the implementation of Chapter VI on Peaceful Settlement of Disputes and Chapter VII of Action with Respect to Threats to the Peace, Breaches of the Peace, and Acts of Aggression (Neudorfer, 2015; White, 2021).

The first UN peacekeeping operation was the UN Truce Supervision Organization (UNTSO), a small operation with dozens of personnel and launched in 1948 in the Middle East to supervise the ceasefire agreement between Israel, Egypt, Lebanon, Jordan, and Syria. To date, there have been 71 peacekeeping operations, which twelve of them are still active in 2020, which are located in Morocco, Central African Republic, Mali, the Democratic Republic of the Congo, Israel, Syria, Cyprus, Lebanon, Sudan, Serbia, South Sudan, India, Pakistan, and the Middle East (UN Peacekeeping, 2021b). As of 31 January 2021 , there are 121 contributing countries that deploy 64,680 troops, 6,966 police forces, 1,896 staff officers, and 1,034 civilians (UN Peacekeeping, 2021a).

The increasing number of peacekeeping personnel reflects the evolvement of peacekeeping operations since 1948. After the end of the Cold War, the UN SecretaryGeneral Boutros Boutros Ghali's in his report "The Agenda for Peace" maintained the role of the UN peacekeeping missions to "support for the transformation of deficient national structures and capabilities, and the strengthening of new democratic institutions" as "social peace is as important as strategic or political peace" (Boutros-Ghali, 1992). Since then, the missions' mandates have been expanded to maintain order and internal security (Simic, 2012), "institution-building, economic recovery, disarmament and reintegration 
of former combatants and facilitation of political processes and elections" (Gowan, 2018). This mandate expansion led to the increase in the number of civilian staff assigned in the missions, although their number has always been far below the uniformed personnel. Moreover, it should be highlighted that peacekeeping operations are still dominated by men. To date, the percentage of women in all peacekeeping missions is only $6.6 \%$, hence the UN Security Council Resolution 2242 (2015) targets to double the number of uniformed women in the missions by 2028 .

The expanded mandates and number of UN peacekeeping personnel then brought a new issue of sexual exploitation and abuse against local communities. During the period of the UN Transitional Authority in Cambodia (UNTAC) in 1993, for example, the number of sex workers drastically increased from 6,000 to 25,000 due to demand from the mission troops (Enloe, 2000; Westendorf \& Searle, 2017). They were not only local Cambodians, but also Vietnamese girls who were trafficked or smuggled to Cambodia (Enloe, 2000). The condition was so apparent that Prime Minister Hun Sen stated that the legacy of the UNTAC in Cambodia was AIDS (Rosas, 2011). However, the responses from the UN were disappointing. The UN Special Representative to Cambodia defended by saying "boys will be boys" (Neudorfer, 2015). Another example was in Bosnia and Herzegovina in 1995 - 1999. Not only there was an increase in the number of women and girls being trafficked to the area, but the personnel also played a role in trafficking the women (Westendorf \& Searle, 2017).

Recognizing the risk of sexual misconduct committed by peacekeeping personnel, in 1998 the UN in the Ten Rules Code of Personal Conduct for Blue Helmet explicitly prohibited the acts of sexual exploitation and abuse. However, in 2001 in Sierra Leone and Liberia, sex exploitation and abuse cases still emerged.

The UN has just begun to take serious actions to address sexual exploitation and abuse in 2003 after the publication of the 2002's UNHCR and Save the Children United Kingdom report on the experience of refugee children in Guinea, Liberia, and Sierra Leone. The report details the experience of these children who were suffered from sexual violence and exploitation from UN peacekeepers in their camps (Grady, 2016). Through Resolution 57/306 (2003) the UN General Assembly requested the UN Secretary-General to compile data on sexual abuse and exploitation, regardless of age and sex of the victims, committed by both peacekeeping members and humanitarian workers. 
Implementing the UNGA Resolution 57/306 (2003), the UNSG in October 2003 published the Secretary-General's Bulletin on Special Measures for Protection from Sexual Exploitation and Sexual Abuse or known as the Zero-Tolerance Policy. This policy distinguishes between sexual exploitation and sexual abuse. The first is defined as "any actual or attempted abuse of a position of vulnerability, differential power, or trust, for sexual purposes, including, but not limited to, profiting monetarily, socially or politically from the sexual exploitation of another." Meanwhile, the latter means "the actual or threatened physical intrusion of a sexual nature, whether by force or under unequal or coercive conditions."

In addressing allegations of sexual exploitation and abuse occurring in peacekeeping missions, the UN builds three approaches, namely prevention, response, and victim assistance. The initiatives in preventing sexual misconduct are i) screening for individuals assigned by governments to a peacekeeping mission, which those who own records of sexual misconduct in previous terms with the UN are prohibited to re-assign in any UN operations; ii) mandatory training on the UN Standards of Conduct to prevent and fight against sexual exploitation and abuse; iii) increasing public awareness on the appropriate behavior of the UN staff and peacekeeping personnel and the reporting mechanisms to file misconduct, and iv) assessing risks related to sexual exploitation and abuse in the field locations.

Further, the UN focuses on ensuring accountability for sexual violators. For allegations involving military and police personnel in UN peacekeeping operations, once the allegations are proven, the UN may take actions to repatriate the individuals and prohibit them to participate in other UN operations. Nevertheless, the responsibility to impose sanctions, from disciplinary to judicial actions, including criminal accountability and child support, is on the national government of the individuals, rather than on the UN capacity.

For the victims, the UN has established various channel to receive sexual allegations from victims. The UN also provides measures to protect victims against reprisal, breach of confidentiality and violence. In addition, the UN extends medical and psychological care, education, basic necessities, legal services, and supports for the 
abandoned children, including paternity and child support claims (United Nations Protocol on the Provision of Assistance to Victims of Sexual Exploitation and Abuse, 2019). The UN mainly funds these services to victims through the Trust Fund in Support of Victims of Sexual Exploitation and Abuse developed in 2016.

Despite the UN's robust initiatives to fight sexual exploitation and abuse in peacekeeping missions, the UN still receives a high number of sexual allegations. As can be seen from Graph 1, after the UN established the reporting channels and digitalized the allegations data in 2007, it received 127 cases. The number has been fluctuated until 2020, with the two highest number of allegations were made in 2009 (112 allegations) and 2016 (104 allegations). The total number of cases the UN received in 2007 - 2020 are 1,099 cases.

\section{Graph 1 Sexual Exploitation and Abuse Over Time (2007 - 2020)}

\section{SEXUAL EXPLOITATION AND ABUSE OVER TIME}

This graph provides information on the total number of allegations reported by year.

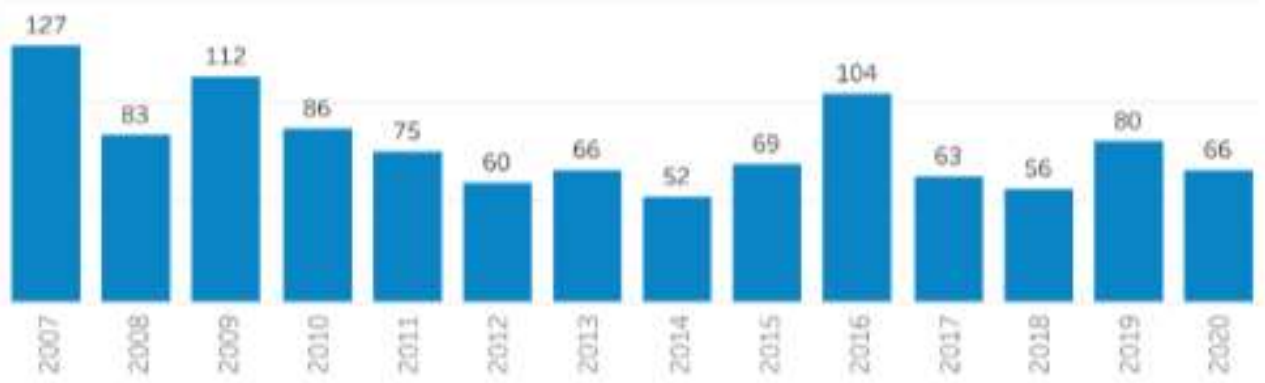

Source: The UN, Sexual Exploitation and Abuse, https://conduct.unmissions.org/sea-overview

It is also important to note that each of the numbers presented in Graph 1 only indicates the number of the reports being brought to the UN, instead of the total victims. Based on UN Data, from 777 allegations made between 2010 - 2020, there have been 1,094 victims identified (UN Conduct in UN Field Missions, 2021). Besides, in some of the reports, the number of victims is still unidentified, meaning that the discrepancy will be even larger than the current calculation. With regard to the paternity claims, the UN records that there have been 316 claims of the baby who were being abandoned by the UN peacekeeping personnel (UN Conduct in UN Field Missions, 2021). 


\section{Conflict, Women Subordination, and Sexual Violence}

Conflict has devastating effects on women. Because conflict is a masculine battle, only men who are allowed to go outside the home. Meanwhile, as women are seen as feminine creatures, helpless, and should be protected from danger, it is only normal for them to stay at home or refugee camps during the. As theoretically contended by Kapur and Reese, when conflicts broke, women with paid work are sent home. As the result, women's unemployment rates in countries with conflict and peacekeeping operations have been high. Based on 2019 UN Women data, the female unemployment rate in host countries for peacekeeping operations such as Syria is $22 \%$, South Sudan is $13.2 \%$, Sudan is $23 \%$, and Pakistan is $6.1 \%$. Even when women have a paid-work during the conflict, their wage is minimal. In the Central African Republic, for example, $67 \%$ of women are employed below the international poverty line, in Congo DR the percentage is $74.6 \%$ and in Mali, it is $52.2 \%$.

It is true that during conflicts, economic activities are disrupted, thus it is logical, either to lay off some of the workers, or lower the wage. However, when the rate of unemployment and the level of wage between men and women are starkly different, the reason is not purely economic, but gendered. It is not only the decreasing demand during a conflict that sends women away from the labor market, but it is the patriarchal cultures that perceive women as feminine members of society who are not fit in a conflict situation. In the case of discriminative wage, it is also the patriarchal cultures that pity women as an object who need jobs to survive regardless of the amount of the wage. This is one of the manifestations of women are placed lesser than men during the conflict.

Moreover, facing unemployment and discriminative wage during the conflict, women then need more protection from men. As the result, women become more subordinated and helpless. At home, because they are poor and at the same time men are suffered from conflict, these women are no longer seen as the protected, but instead as the liability. They will therefore, either face violence inside their home, or they need to 
independently look for protection or opportunities outside their house. Both of the options will lead to the women's vulnerability to male violence.

Outside women's houses there are peacekeeping mission personnel who are deployed to protect women and children. Among the personnel, there are groups of individuals who hold hyper-masculinism ideas that perceive local women as helpless objects. Their misogynistic ideas and superiority are the main factors of sexual exploitation and abuse against the population that they are supposed to protect. There are four forms of sexual exploitation and abuse committed by peacekeepers against local women that observed by Westendorf and Searle, namely opportunistic sexual abuse, planned sadistic abuse, transactional sex, and networked sexual exploitations and abuse (Westendorf \& Searle, 2017).

Opportunistic sexual abuse is rape committed by the violator for private purposes, unplanned, and without coordination with other personnel. Second, planned sadistic abuse is an extreme form of rape that involves brutality, torture, and murder that has been preplanned and is committed for pleasure. Third, transactional sex exchanges sexual relations for money, food, cloth, or employment. The element of consent in this transactional sex is relatively blurred due to the asymmetric power that existed between peacekeepers and local women. Forth, networked sexual exploitation and abuse are related to the growth of the sex industry, human trafficking, and peacekeeping personnel relations with transnational organized criminals.

Every member of peacekeeping mission, either they are military, police forces, or civilian experts, may possess hyper-masculine characteristics. Therefore, each of them has the same probability to commit sexual exploitation and abuse. However, as shown in Graph 2, it is military personnel who received most of the allegations on sexual exploitation and abuse. Out of 1,100 perpetrators identified by the UN internal investigation in $2007-2020$, there are 600 persons, or 54\%, who belong to military contingents investigation in $2007-2020$, there are 600 persons, or 54\%, who belong to military contingents.

Even with the reporting mechanisms established by the UN for sexual misconduct by peacekeepers, it is difficult to capture the real number of sexual violators, including from the military. As the first step of reporting mechanisms require the victims to report to the head of the mission, who oftentimes are a military member, there is always a risk 
of solidarity and fraternity among military personnel to protect their fellows. If the reporting mechanisms had involved an independent body without any affiliation to military peacekeeping missions, perhaps the number of cases substantiated by the UN would have been higher.

Graph 2 Category of Personnel Committed Sexual Exploitation and Abuse 2007 - 2020

Category of Personnel Committed Sexual Exploitation and

Abuse 2007 - 2020

Military Police Civilian Unknown

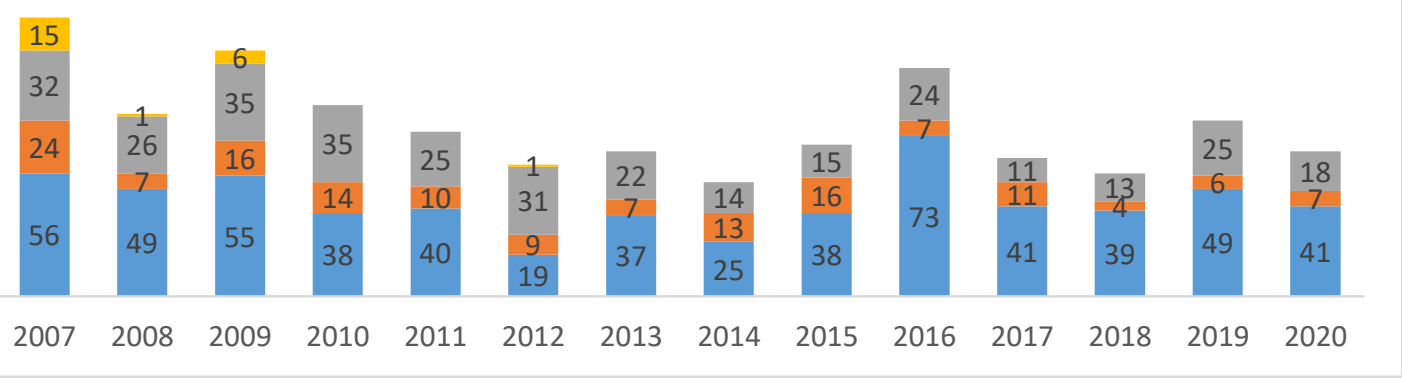

Source: Sexual Exploitation and Abuse, https://conduct.unmissions.org/sea-overview

\section{The WPS Index of the Host and Contributing Countries}

It is not only the militaristic environment that nurtures the hyper-masculinism behavior of the peacekeeping troops, but also the patriarchal cultures inside the home countries. Currently, contributing countries with the deployment of troops, police, civilian experts, and staff officers more than 1,000 personnel as of 31 January 2021 are Bangladesh, Rwanda, Ethiopia, Nepal, India, Pakistan, Egypt, Indonesia, China, Ghana, Senegal, Chad, Tanzania, Morocco, Togo, Burkina Faso, Italy, Uruguay, Cameroon, South Africa, and Zambia. It is then observed that both the host countries and the contributing countries share similar characteristics, which are developing countries and experiencing intrastate conflicts, or just entering the peace-building phase after the major conflict ceased. This shared fate of intrastate conflict explains a lot about the poor condition of women inside the home countries. 
Further, when we look at the WPS Index, another similar feature emerges, which is the majority of the host and contributing countries lie at the bottom of the WPS ranks. The first exception is UNTSO (UN Truce Supervision Organization) in which the host country (Israel) and contributing countries are developed and placed high in WPS ranks. The second exception is UNMIK (UN Interim Administration Mission in Kosovo), in which Serbia as the host country is placed among the top-25 countries in the WPS Index and some of the contributing countries also enjoy high scores for their WPS Index.

Table 1 summarizes the data of the WPS Index of the host and contributing countries.

\begin{tabular}{|c|c|c|c|c|c|c|}
\hline No & $\begin{array}{c}\text { Year } \\
\text { of } \\
\text { Operations }\end{array}$ & Mission & $\begin{array}{c}\text { Host } \\
\text { Countries/ } \\
\text { Location }\end{array}$ & $\begin{array}{c}\text { Top } 5 \\
\text { Contributing } \\
\text { Countries }\end{array}$ & $\begin{array}{l}\text { WPS } \\
\text { Index } \\
2019\end{array}$ & $\begin{array}{r}\text { WPS } \\
\text { Rank } \\
2019\end{array}$ \\
\hline \multirow[t]{7}{*}{1} & \multirow[t]{7}{*}{$1991-2020$} & MINURSO (UN & Western Sahara, & & 0.625 & 133 \\
\hline & & Mission for the & Morocco & & & \\
\hline & & Referendum in & & Bangladesh & 0.612 & 142 \\
\hline & & Western Sahara) & & Egypt & 0.583 & 151 \\
\hline & & & & Ghana & 0.724 & 78 \\
\hline & & & & Pakistan & 0.46 & 164 \\
\hline & & & & China & 0.725 & 76 \\
\hline \multirow[t]{6}{*}{2} & \multirow[t]{6}{*}{$2014-2020$} & MINUSCA (UN & Central Africa & & 0.513 & 160 \\
\hline & & Multidimensional & & Rwanda & 0.743 & 65 \\
\hline & & Integrated & & Pakistan & 0.46 & 164 \\
\hline & & Stabilization Mission & & Bangladesh & 0.612 & 142 \\
\hline & & in the Central & & Egypt & 0.583 & 151 \\
\hline & & African Republic) & & Cameroon & 0.597 & 148 \\
\hline \multirow[t]{6}{*}{3} & \multirow[t]{6}{*}{$2013-2021$} & MINUSMA (UN & Mali & & 0.539 & 159 \\
\hline & & Multidimensional & & Bangladesh & 0.612 & 142 \\
\hline & & Integrated & & Chad & 0.553 & 156 \\
\hline & & Stabilization Mission & & Senegal & 0.661 & 114 \\
\hline & & in Mali) & & Togo & 0.665 & 113 \\
\hline & & & & Egypt & 0.583 & 151 \\
\hline \multirow[t]{4}{*}{4} & \multirow[t]{4}{*}{$2010-2020$} & MONUSCO (UN & Congo DR & & 0.512 & 161 \\
\hline & & Organization & & India & 0.625 & 133 \\
\hline & & Stabilization Mission & & Pakistan & 0.46 & 164 \\
\hline & & in the Democratic & & Bangladesh & 0.612 & 142 \\
\hline
\end{tabular}




\begin{tabular}{|c|c|c|c|c|c|c|}
\hline & & Republic of the & & Morocco & 0.625 & 133 \\
\hline & & Congo) & & South Africa & 0.741 & 66 \\
\hline \multirow[t]{8}{*}{5} & \multirow[t]{8}{*}{$1974-2020$} & \multirow{2}{*}{$\begin{array}{l}\text { UNDOF (UN } \\
\text { Disengagement }\end{array}$} & \multicolumn{4}{|l|}{ Golan } \\
\hline & & & Israel & & 0.815 & 34 \\
\hline & & \multirow[t]{6}{*}{ Observer Force) } & Syria & & 0.416 & 165 \\
\hline & & & & Nepal & 0.717 & 84 \\
\hline & & & & Uruguay & 0.757 & 58 \\
\hline & & & & India & 0.625 & 133 \\
\hline & & & & Ireland & 0.858 & 16 \\
\hline & & & & Fiji & 0.757 & 58 \\
\hline \multirow[t]{6}{*}{6} & \multirow[t]{6}{*}{$1964-2021$} & \multirow{6}{*}{$\begin{array}{l}\text { UNFICYP (UN } \\
\text { Peacekeeping Force } \\
\text { in Cyprus) }\end{array}$} & Cyprus & & 0.819 & 31 \\
\hline & & & & United Kingdom & 0.883 & 7 \\
\hline & & & & Slovakia & 0.813 & 35 \\
\hline & & & & Argentina & 0.775 & 48 \\
\hline & & & & Ireland & 0.858 & 16 \\
\hline & & & & Chile & 0.764 & 55 \\
\hline \multirow[t]{6}{*}{7} & \multirow[t]{6}{*}{$1978-2020$} & \multirow{6}{*}{$\begin{array}{l}\text { UNIFIL (UN Interim } \\
\text { Force in Lebanon) }\end{array}$} & Lebanon & & 0.599 & 147 \\
\hline & & & & Italy & 0.826 & 28 \\
\hline & & & & Indonesia & 0.703 & 95 \\
\hline & & & & France & 0.847 & 20 \\
\hline & & & & Nepal & 0.717 & 84 \\
\hline & & & & Ghana & 0.724 & 78 \\
\hline \multirow[t]{6}{*}{8} & \multirow[t]{6}{*}{$2011-2020$} & \multirow{6}{*}{$\begin{array}{l}\text { UNISFA (UN } \\
\text { Interim Security } \\
\text { Force for Abyei) }\end{array}$} & Sudan & & 0.547 & 163 \\
\hline & & & & Ethiopia & 0.651 & 121 \\
\hline & & & & Zimbabwe & 0.726 & 74 \\
\hline & & & & Rwanda & 0.743 & 65 \\
\hline & & & & Ghana & 0.724 & 78 \\
\hline & & & & Nepal & 0.717 & 84 \\
\hline \multirow[t]{6}{*}{9} & \multirow{6}{*}{$\begin{array}{l}1999 \text { - open- } \\
\text { ended }\end{array}$} & UNMIK (UN Interim & Kosovo, Serbia & & 0.839 & 24 \\
\hline & & Administration & & Ukraine & 0.689 & 105 \\
\hline & & Mission in Kosovo) & & Czech Republic & 0.82 & 30 \\
\hline & & & & Hungary & 0.772 & 49 \\
\hline & & & & Russia & 0.77 & 51 \\
\hline & & & & Turkey & 0.661 & 114 \\
\hline 10 & $2011-2021$ & & South Sudan & & 0.479 & 163 \\
\hline
\end{tabular}




\begin{tabular}{|c|c|c|c|c|c|c|}
\hline & & UNMISS (UN & & Rwanda & 0.743 & 65 \\
\hline & & Mission in the & & India & 0.625 & 133 \\
\hline & & Republic of South & & Ethiopia & 0.651 & 121 \\
\hline & & Sudan) & & Nepal & 0.717 & 84 \\
\hline & & & & Bangladesh & 0.612 & 142 \\
\hline 11 & 1949 - open- & UNMOGIP (UN & India and Pakistan & & & \\
\hline & ended & Military Observer & India & & 0.625 & 133 \\
\hline & & Group in India and & Pakistan & & 0.46 & 164 \\
\hline & & Pakistan) & & Croatia & 0.818 & 32 \\
\hline & & & & Philippines & 0.709 & 90 \\
\hline & & & & Republic of & 0.816 & 33 \\
\hline & & & & Korea & & \\
\hline & & & & Sweden & 0.879 & 9 \\
\hline & & & & Thailand & 0.707 & 92 \\
\hline 12 & 1948 - open- & UNTSO (UN Truce & Middle East (HQ: & & 0.815 & 34 \\
\hline & ended & Supervision & Jerusalem) & & & \\
\hline & & Organization) & & Finland & 0.891 & 3 \\
\hline & & & & Australia & 0.844 & 22 \\
\hline & & & & Netherlands & 0.879 & 9 \\
\hline & & & & Denmark & 0.891 & 3 \\
\hline & & & & Ireland & 0.858 & 16 \\
\hline
\end{tabular}

Source: (Author and Georgetown University’s Institute for WPS, 2019)

From the table, there are seven host countries whose WPS Index are among the lowest, namely Mali (159), Central African Republic (160), Congo DR (161), Sudan (163), South Sudan (163), Pakistan (164) and Syria (165). Although the fact is depressing, the poor performance of these countries in the WPS Index is not surprising. The ongoing conflict is depriving women's freedoms and access to the public sphere. Under this condition, women in host countries are excluded, discriminated and prone to violence, thus these countries' ranks in WPS Index are the lowest.

The most terrifying fact from the table is that many of the contributing countries' rank is below the 100th. They are: Mexico (103), Ukraine (105), Zambia (107), Togo (113), Senegal (114), Turkey (114), Bhutan (118), Ethiopia (121), Malawi (130), Morocco (133), Guinea (133), India (133) Burkina Faso (136), Cote de Ivoire (138), 
Burundi (139), Bangladesh (142), Cameroon (148), Egypt (151), Mauritania (151), Sierra Leone (153), Niger (155), Chad (156), and, Pakistan (164).

As the WPS Index classifies them to the fourth and fifth quintile, the same rank as the host countries, the condition of women inside the contributing countries does not deviate much from the host countries. This means that in the aforementioned home countries, the ways men, including military males, perceive and treat women will be similar to the ways in host countries. Since in home countries male peacekeepers are accustomed to seeing women as an object, poor, helpless and subordinated, they will replicate these patriarchal views to women in the host countries.

Graph 3 Allegations of Sexual Exploitation and Abuse by Nationality of Perpetrators year 2015 2020

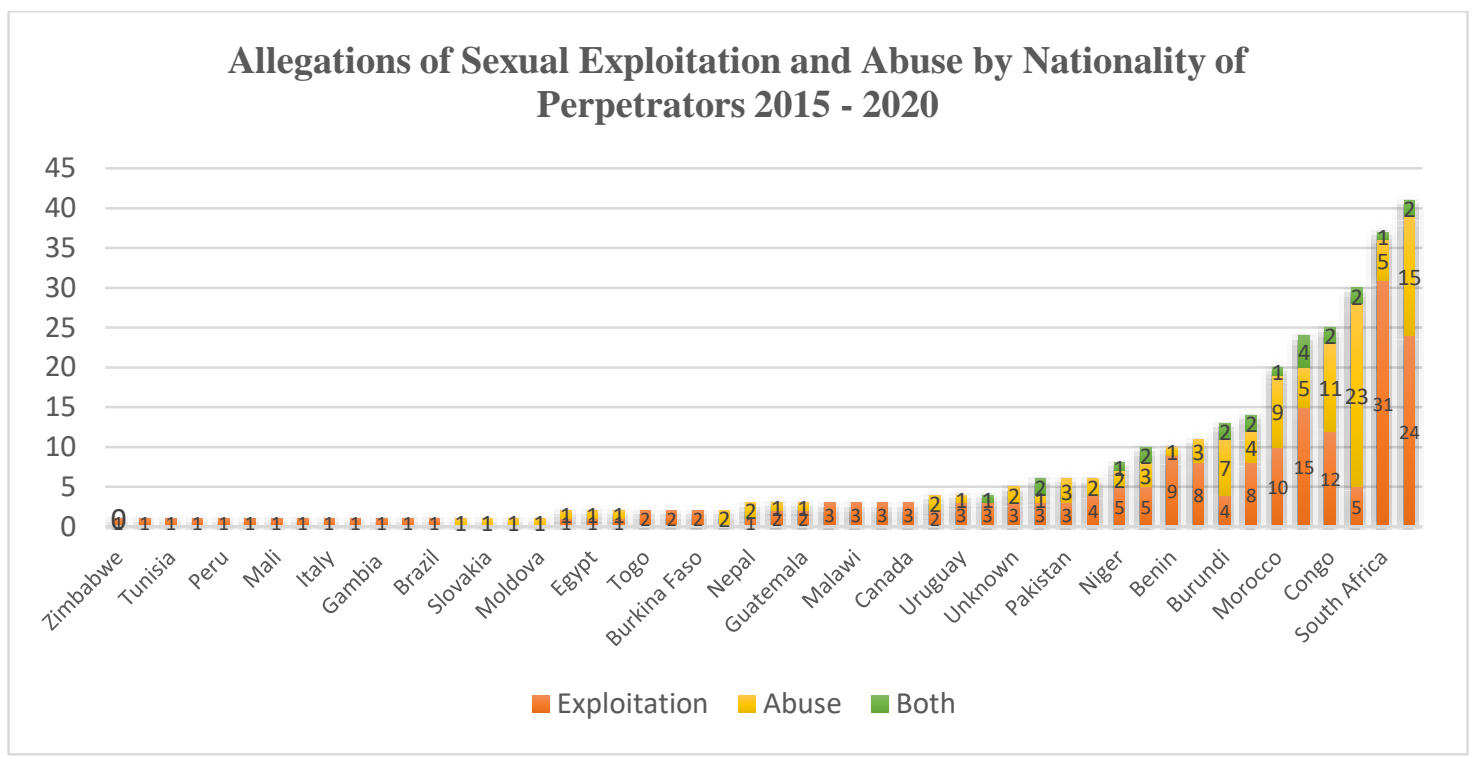

Source: Sexual Exploitation and Abuse, https://conduct.unmissions.org/sea-overview

Moreover, since the UN assigns peacekeeping missions with the mandate to protect civilians, there is a sense of superiority attached to these male troops towards the local population, especially women. The peacekeepers will probably subjugate local women, because of their gender and lower status of country. Hence, deploying troops coming from countries with low scores on WPS Index is equal to exporting more of the patriarchal forces to a community whose women are already devalued. As the result, with 
the existence of peacekeeping operations, women in the host countries face the risks of sexual violence. Graph 3 shows the UN Data on the nationality of perpetrators of sexual exploitation and abuse compiled in 2015-2020. Cameroon, South Africa, Democratic Republic of Congo, Congo, Gabon, Morocco, Tanzania, Burundi, Senegal, Benin, Mauritania, Niger, and the following countries are among the worst performer countries in WPS Index.

\section{The Gendered Intention of the Contributing Countries}

Through gender analysis, this paper argues that the effective measures to diminish the risk of sexual misconduct in a conflict situation are by reducing the influence of the patriarchal cultures that subordinate women and induce the states to perform masculine identity as the protector. Further, this paper proposes measures for the UN to minimalize the risk of sexual exploitation and abuse by the peacekeeping personnel against local women.

It is alarming to note that some of the contributing countries that perform bad in WPS Index also receive the highest number of sexual misconduct allegations. Besides, these countries are not the best in military logistical supply and arrangements that the UN should back up their military equipment to support the mission. It is then intriguing to analyze the factors that drive these countries to keep sending forces, but compromise the mandate to protect the women and children.

First, it is important to underline that these countries have been or are still experiencing conflict, either with the ethnic minority, opposition groups, or rebellion. They are also economically poor and underdeveloped. Two, it should be admitted that the elements of protection, peace, and security are sacred both to the UN Charter and the patriarchal cultures. The two backgrounds support the concept of state project as contended by Jackson and Nixon and the theory of performativity of states as coined by Wadley.

The formation of states, or the state project, extends beyond the completion of territorial boundaries and the recognition of sovereignty. Therefore, for countries that have just enacted their physical border and declared sovereignty, they need to do the next stage of state formation, which is yoking. Each of the contributing countries in fact have this interest. Countries such as Cameroon, Congo, Senegal, Gabon, Ghana, Mauritania, 
have the similar characteristic that their current regimes are relatively successful in maintaining state unity despite their internal conflict. Meanwhile for Burundi and DR Congo, just in 2006 and 2010, respectively, they graduated from being the host countries for UN peacekeeping missions. Then, Morocco, which despite its part of the territory is still hosting a UN peace mission, it still has a legitimate government. Last, Benin and Tanzania. They are relatively stable although they face a serious poverty.

After these countries maintain their border and internal unity, they have the aspiration to substantiate their identity as strong, capable masculine states. They want to erase their long-attached identity as countries with a long history of internal conflict and poverty, weak, vulnerable, helpless, or in other words: feminine.

To achieve this gendered intention, the yoking process undertaken by these states involves adopting masculine ideas that are accepted, legitimated, and meaningful in the international system. Conventionally, the masculine identity is awarded by taking part and winning the war. However, with the new concept of peacekeeping operations to maintain international peace by protecting civilians in weak, vulnerable, helpless, feminine countries, applying masculine ideas now has its means and justification. These countries, therefore, contribute their large number of troops to the UN peacekeeping missions. This gendered intention is perfectly concealed since the legitimation of peacekeeping operations is secured in the UN Charter and the UN Security Council Resolution.

Further, their participation in the peacekeeping missions also demonstrates that they are among the masculine actors in the international system. The number of forces they submit to the peacekeeping missions is displayed in the UN websites and media channels. It is also articulated in the various speeches and reports of the UN bodies. More importantly, the number is appreciated by the other UN Member States, including the developed, superpower countries that fund the UN peacekeeping missions. With all of the praises, these countries then successfully place their position within the network of the historically masculine states, such as the United States, the United Kingdom, France, Germany, Belgium, etc. Hence, it is significant for them to be in the spotlight and maintain this reputation. 
The result of these gendered state formation and performativity then appears on the unequal relations between the contributing states and the host states and the quality of protection extended to the host countries. The first countries believe they are superior to the latter group, thus they treat the locals, especially women, as an object. This superiority feeling then provides a basis to manipulate local women to exchange sex with money, food, and cloth, or to coerce women who reject the offer. Under the patriarchal cultures and gendered state formation and performativity, therefore, peacekeeping operations deployed by countries with the worst performance in WPS Index, serve more to manifest their masculine identity rather than to protect the women in the host countries as upheld by the UN Charter Chapter VI and VII.

\section{Conclusion}

The expansion of mandates of the UN peacekeeping missions from monitoring cessation agreements to protecting civilians and assisting the transformation of national structures and capabilities is essential to maintain international peace and stability as enshrined in the UN Charter. Nevertheless, this expansion increases the risk of sexual exploitation and abuse against local women who are supposed to be protected under the missions. To address this problem more effectively, the UN should perceive the problem from a different perspective. With the pervasiveness of patriarchal cultures, the UN needs to analyze the issue through the gender perspective to formulate better means to protect women in host countries.

First, it should be noted that during and after conflict, women are suffered from limited opportunities to take part in public spheres, hence they become poorer and more subjugated, which leads to their vulnerability to male violence. Giving local women wider access to education, political realm, market, and property is a must, especially after the deployment of UN peacekeeping missions. However, the effort would not be adequate if it was only articulated through empty encouragement. The UN peacekeeping personnel should actively create a better atmosphere and sound forums for local women to participate in public spheres. One of the ways is through cooperation with humanitarian bodies under the UN or with independent CSOs. Another way is by urging the local government to open access for women education, employment and political party and legislative seats. 
Second, the reporting mechanisms for sexual exploitation and abuse should be more accessible, safe, confidential for the victims, and independent from the peacekeeping missions deployed. The problem of under-reporting and the risk of covering up for peers' misconduct are still apparent that the victims are reluctant to report. Getting the most precise number of cases is essential since it may magnify the scopes of the problems to the UN Member States. It will also urge the contributing countries to be more responsible in bringing the perpetrators to justice and providing a remedy to the victims.

Third, the UN should be more selective in calling the Member States to contribute to peacekeeping missions. The UN assessment to contributing countries should cover more gender-based indicators to select the least patriarchal operations. Although currently the number of peacekeeping personnel is still under the UN target, welcoming all countries merely because they show a willingness to take part in UN missions may compromise the safety and dignity of the local communities, especially women.

These three measures then highlight the importance of employing the WPS Index to assess the countries' suitability and capability to participate in the peacekeeping missions as the protector. Although the WPS Index is still new and there are other indexes related to women and gender equality, since the WPS Index includes the measure of women security that portrays the degree of the patriarchal cultures in a country, the Index will serve as a sound basis for enforcing gender-mainstreaming in the peacekeeping missions.

Employing the WPS Index as part of the gender-mainstreaming efforts in peacekeeping missions may also be more straightforward for short and medium term than increasing female peacekeepers as targeted by the UNSC Resolution 2242 (2015). As known, the number of female troops and police in most of the UN Member States has been historically and structurally minimal. It will take a long time for the countries to fulfill the vacancy for the uniformed female to the peacekeeping missions. Besides, doubling the number of women will not quickly and instantly solve the problems of women's subordination as well as sexual exploitation and abuse. The solution to these problems is not as simple as replacing the men with women, as if the women were the quick fix. The problem of gender inequality is stemmed from the patriarchal cultures that 
are strongly instilled in the societies. Protecting local women from sexual misconduct should be done by reducing their interaction with males with strong hyper-masculine behavior. Peacekeeping missions therefore should be composed of personnel with experience of living equally with women in a society.

Last, more active roles from developed countries that have a higher score in WPS Index are also relevant. It is not sufficient for them only to fund the missions. Even if the domestic law binds the capability of these developed countries to send troops to peacekeeping missions, they should be more critical in assessing the gender issues in countries that send missions. It is part of their responsibility to stop sexual exploitation and abuse in the peacekeeping missions since they allocate a large budget for these activities.

\section{References}

Boutros-Ghali, B. (1992). An Agenda for Peace. In International Relations (Vol. 11, Issue 3). https://doi.org/10.1177/004711789201100302

DeLargy, P. (2013). Sexual Violence and Women's Health in War. In C. Cohn (Ed.), Women and Wars. Polity Press.

Enloe, C. (1993). The Morning After. University of California Press.

Enloe, C. (2000). Manuevers (The Regent).

Georgetown University's Institute for WPS. (2019). 2019 Women Peace and Security Index. https://giwps.georgetown.edu/the-index/

Gowan, R. (2018). Peace Operations. The Oxford Handbook on the United Nations, March, 419-445. https://doi.org/10.1093/oxfordhb/9780198803164.013.23

Grady, K. (2016). Sex,statistics,peacekeepers and power: UN data on sexual exploitation and abuse and the quest for legal reform. Modern Law Review, 79(6), 931-960. https://doi.org/10.1111/1468-2230.12225

Hudson, H. (2010). Peace Building through a Gender Lens and the Challenges of Implementation in Rwanda and Cote d'Ivoire. In L. Sjoberg (Ed.), Gender and International Security, Feminist Perspectives. Routledge.

Jackson, P. T., \& Nexon, D. H. (1999). Relations before states: Substance, process and the study of world politics. European Journal of International Relations, 5(3), 291332. https://doi.org/10.1177/1354066199005003002

Kapur, B., \& Rees, M. (2019). WPS and Conflict Prevention. In S. E. Davies \& J. True (Eds.), The Oxford Handbook of Women, Peace, and Security. Oxford University Press.

Neudorfer, K. (2015). Sexual Exploitation and Abuse in UN Peacekeeping (Lexington).

Rosas, S. (2011). Sex Trafficking in Cambodia as a Complex Humanitarian Emergency. Advocates' Forum, 41-50. https://crownschool.uchicago.edu/sex-traffickingcambodia-complex-humanitarian-emergency 
Simic, O. (2012). Regulation of Sexual Conduct in UN Peacekeeping Operations. Springer.

Ticker, J. A. (1992). Gender in International Relations. Columbia University Press.

UN Conduct in UN Field Missions. (2021). Sexual Exlploitation and Abuse.

UN Peacekeeping. (2021a). Global Peacekeeping Data.

UN Peacekeeping. (2021b). Where We Operate.

United Nations Protocol on the Provision of Assistance to Victims of Sexual Exploitation and Abuse, 1 (2019) (testimony of UN Secretariat).

Wadley, J. D. (2010). Gendering the State: Performativity and Protection in International Security. In L. Sjoberg (Ed.), Gender and International Security, Feminist Perspectives (p. 283). Routledge.

Westendorf, J. K., \& Searle, L. (2017). Sexual exploitation and abuse in peace operations: trends, policy responses and future directions. International Affairs, 93(2), 365-387. https://doi.org/10.1093/ia/iix001

White, N. D. (2021). Peacekeeping and International Law Peacekeeping and International Law Legal framework: UN Charter and international law. March, 119. https://doi.org/10.1093/oxfordhb/9780199686049.013.17 